\title{
Cultural Fusion from the Perspective of Translation
}

\author{
Baochun LI, Jinling LIU \\ Huaiyin Institute of Technology, HuaiAn, 223003, Jiangsu \\ 1091997998@qq.com
}

\begin{abstract}
As there are many differences between Chinese culture and the Western cultures, such as history, religion, tradition, philosophy and geography, there are significant factors in the aspects of language and words. As for this, people start to learn about the languages of each other and understand the meanings of the words. At this time, the translation has become the most important method of the communication of cultures between China and West. The aim of translation is not only to translate the literal meaning but also the cultures in words. Translators help readers know the relationship and meanings between the source language and the translated language from the points of skills and methods of translation. It can make them know Chinese culture and Western cultures and promote cultural fusion deeply. In this thesis, the author discusses how to eliminate cultural conflicts, absorb, accept and fuse the culture of each other from the perspective of translation. Then, it can make translation more effective and it will increase the interflow and fusion. We conclude the development of Chinese and western culture and fusion from the methods and skills of translation. At the same time, we can neutralize the conflict between the cultures through translation.
\end{abstract} tication.

Index Terms - translation; cultural fusion; alienation; domes-

\section{Introduction}

As a tool of interlingual communication, translation is not only a conversion process of language but also a process of cultural transmission. Different countries and nations have different culture because of their separate living environment, religion, social system. So, how to cross the the barriers between cultures and handle cultural factors of source language is the key to translation.We generally know that we cannot translate words ignoring their culture. E.A. Nida, the famous translator said, "For truly successful translating, biculturalism is even more important than bilingualism, since words only have meanings in terms of the cultures in which they function." (E.A.Nida, 2001: 23) It also means the development of the translation is also a process of cultural fusion.

\section{The background and definition of cultural fusion}

\section{A. The background of cultural fusion}

In 1980s, the book called People and Culture (Bowmar, 1980: 63) is very popular in America. There is a paragraph in the book--In the morning, an American wakes up from his imitation of the Near East style bed........He lifts the pure cotton quilt from India, and puts the curtain which produced by Near East on the bed. Then, he takes off his pajamas from India, and starts to wash his face with the soap made in France.......After he dresses in the leather coat which is from Asian nomads, he begins to have lunch. He eats the oranges from the middle of The Mediterranean first and then the muskmelon form
Persia........After that he drinks the coffee form Africa. He picks up a newspaper that the the paper itself and art of printing are both from ancient china.......How is this person? Actually, he is totally a American. From the short paragraph, we can see the globalization and the communication among the cultures.

In the past decades, the concept of globalization has been accepted by most people, And it has been an inevitable factor in our daily life. The world seems to be a global village. From the discovery of the New World in 1492, the total world starts to unite. The original independent development of each area and different countries begin to communicate and fuse through economy, religion, venture, war and so on.

\section{B. The definition of cultural fusion}

In the procedure of the communication of cultures, Chinese people can learn about the history, tradition and lifestyles of the Western countries with the development of globalization and translation. At the same time, Western people can know the Chinese culture too. In the procedure, two kinds of cultures communicate with each other.

\section{Differences in thinking between West and Chinese people}

The western people are used to the logical and abstract thinking while Chinese people prefer the imaginal thinking. We can see it from the differences between the form of Western and Chinese words. As they have disparate history, religion, tradition, and languages, they will have a great difficulty in understanding meanings of words in the other side. Spontaneously, the translation is a great difficulty. Compared with abstract thinking, material culture has more reified and trivial effect on translation. Besides, the material cultural influence of geographical environment and tradition are shown in almost all literature.

For example to the translation of east wind and west wind. The east wind in Chinese people' s mind is warm and soft. It represents the coming of spring, beautiful things and vigor, such as the sentence "with the spring breeze of reform and opening up (乘着改革开放的东风)”. We cannot directly translate into "with the east wind of reform and opening up" because the east wind is biting cold in the English minds while the west wind is warm and soft because of the geographical location of Britain. It resulted in the mistake of understanding of each other and cannot promote the cultural fusion. So we can see the importance of translation in terms of understanding of culture between Chinese and West.

Besides, Li Shangyin wrote in his poem Wuti “相见时难 别亦难, 东风无力百花残” . (HU Wenzhong, 1999: 167) Here, the east wind is the angel to fouth flower open. Then, he 
felt sad about the withered flowers because of lacking the "east wind".

As far as the translation of this sentence is concerned, there are two samples:

1) Hard it was to see each other -harder still part!

The east wind has no force.

Herdan)

The hundred flowers wither.(translated by Innes

2) It's difficult for us to meet and hard to part; the east wind is too weak to revive flowers dead. (translated by $\mathrm{Xu}$ Zhongyuan)

In the two translations, two translators translate “东风” into "the east wind". However in the eyes of western people, it has lost the feeling of gentle and light absolutely.

\section{Cultural fusion from the perspective of domestication and foreignization}

According to the problem of how to handle the culture in process of translation, translators often have two opposite points of view-domestication and foreignization. (Leo Hickey, 2001, 117) Domestication means that to target at the object language and readers, translators make the methods of expression naturally and try their best to take the behavior patterns of original language into consideration because of the culture of readers of translation contents. However, foreignization means that in order to target at original language and original author, translators make the expression of translation keep the features of origin and do their best to make the target readers accept original culture. In the process of translation, although most people acknowledge that both foreignization and domestication are indispensable strategies to deal with the problems of culture in process of translation. They can indicate the communication of culture and the use of specific methods depending on the aim of translators and the intentions of translation.

\section{A. Foreignization}

\section{1)Positive meaning of foreignization in cultural fusion}

From the angle of language translation, foreignization can transfer one language and the information to another and almost keep its original form. It can bring the object language new things. At the same time, the fangle can lead the changes and the development of object language and promote the integration of cultures between different countries and nations.(Peter Newmark, 2001: 98) From the angle of exchange of cultures, first of all, we need to respect the cultures of other countries, which can help us reflect foreign cultures honestly on the basis of equality. On the culture itself, it is a open system that has the immeasurable capacity of containing and absorbing. With the development of global integration, the outside new things have been accepted by people more and more easily. It help to broaden the readers' horizon and make the foreignization possible. Besides, culture has a strong penetration. At the background of globalization, alienation can help acknowledge, understand and absorb foreign cultures and enrich the cultural wealth of native. It accords to the penetration of each other and blending with each other. In the studies of translation, we can find the translation through foreignization is more appropriate and suitable and be accepted by most readers in their daily life.

2)The specific methods of translation under alienation

To be specific, we can divide it into two circumstances: first one is that when we translate we just need simply alienation, then we can express the meaning of original content clearly and vividly. In this circumstance, we can use alienation and keep the cultural features as far as possible. The other circumstance is in which the readers of translation content can not understand totally the meanings of original content and they may be mislead. Then, we must take the strategy of alienation with domestication to translate. We focus on alienation and spread the cultural massage of origin content, replenishing with domestication. It can make readers feel the cultural features and understand the meaning of original content.

a) Literal translation

Literal translation, is a way to translate in which translators keep the methods of metaphor and image and national features and we avoid the language specification and make errors and mistakes. Besides, it is worth to notice that the literal translation is not equal to literal translation. For example, “move heaven and earth” does not mean “翻天覆 地” in Chinese, but the meaning of “用尽各种方法, 竭尽全 力” . “eat one's words” does not mean “食言”, but express “承认说错了话”. And “fat farm”means “减肥中心” not the meaning of “脂肪农场” . (HE Ziran, 1988: 201) Because there are many fields that people have the similarities, such as the emotion, the feeling of objective physical things and the social experience, there are a small quantity of same or similar methods of expression in Chinese and English. These expressions may have the same or similar literal meanings, imaginable meanings and implied meaning. That is to say, the cultural information they convey is same and will not make the mistakes but make readers understand more easily. At the same time, it can represent the cultural information under the original language directly.

From the following examples, we can see that.

“他一家子在这儿, 他房子、地在这儿, 他跑? 跑得了 和尚, 跑不了庙。” (周立波: 《暴风骤雨》)

Escape? But his home and property can't escape. The monk can run away, but the temple can not run with him.

“孩子们这么大了, “没吃过猪肉, 也见过猪跑”。” （曹雪芹: 《红楼梦》，第16回）

The boy is grown up now. He is old enough to have seen a pig run, even if he has not yet tasted pork himself.

From these translation, readers can know that tiger is considered as the most awesome and violent animal in Chinese eyes and understand Chinese culture better.

b) Transfer

Transfer is the method that translators put the original words into the translation content without any change. It is very common in Chinese and we have used the method many years. It is suitable for many introduced new things, such as 
“OK, Byebye, PK, GDP, CT". They have been common in our daily life. And I think it is the best evidence of cultural confusion.

\section{c) Transliteration}

We can use transliteration when we can not find the suitable words in the translation language to replace the original words. And this methods make many new words and fangle enter into China. Here I list some common words in our daily life, such as “雷达”(radar), “扑克” (poker), “吗啡” (morphine), “高尔夫” (golf), “巧克力” (chocolate), “沙 发” (sofa). Nowadays, they have been common expression and can understand their meanings accurately.

\section{B. Domestication}

1) Positive meaning of domestication in cultural fusion

Domestication refers to that translators adapt the attitudes of ethnocentrism and make the original language transfer to the value of translation content. It brings the author the original language to the translation language. Due to the different methods of thinking between the Chinese and West, it is necessary to change the subsequence of sentence when translating. For example, there is a Chinese proverb, “情人眼 里出西施”. When translating it, we must consider the cultural of translation content and translate it into "Beauty is in the eye of the beholder".

2) The specific methods of translation under domestication--Paraphrasing

Paraphrasing means that we abandon the strange and hardunderstanding figurative images on the basis of fully understanding the original content. Translators try to find the cultural equivalence between the original contents and translation contents. The feature of paraphrasing is avoiding the cultural barriers and convey the information and meaning of original contents and make it easy to understand. When we translate the following sentence, we can use paraphrasing.

And I do not mistrust the future; I do not fear what is ahead. For our problems are large, but our heart is larger. Our challenges are great, but our will is greater. And if our flaws are endless, God's love is truly boundless.

我并非不信任未来; 我并不害怕我们面临的问题。我 们的问题很多, 但我们的心胸更宽广。我们面临的挑战很 严峻, 但我们的决心更大。如果说我们的弊病层出不穷的 话, 那上帝的爱更是真正的广衰无边。

\section{The features of domestication and foreignization}

Domestication can help the readers of translation contents understand the meanings and the cultural information of original contents, but sometimes it will overspread the cultural features of origins. While alienation can keep the original features, but sometimes translation readers can not understand its meanings. So,when we translation, we should combine domestication with alienation. And we can see they both can promote the cultural fusion and help the communication of different cultures and translations.

\section{Cultural Fusion from the Perspective of Translation}

\section{A. The theory of translation}

The destination of translation by Nida and Taber is that translation is accepting reproducing of languages and the closest natural equivalent. The first class is the meaning and second is literary form. (HU Gengshen, 1998: 10) Even-Zohar sees translation as a process of negotiation between two cultures: translation is acculturation. Another normal form representative personage of hermeneutics - Gadamer H.G. put $\mathrm{s}$ forward his view to translation: the task of the translator is not to copy the original content, but put yourself in the original content. Only in this way, the translator can transfer the original content to his words with his own dis course intention. The normal form translators considered that translation is not only an exchange of language but also the cultural interaction of three aspects including the process of translation, products and acceptance. The Belgium scholar Andre Levefere greatly approved the conclusion between translation and culture.by Even-Zohar-translation is indeed acculturation. Some scholars of our country also start to perceive that when translating we need to take culture into consideration. For example, Wang Kefei makes a definition of translation: translation is a cultural movement. Translators make out the meanings of one language into another language. In conclusion, there are two requirements on translation studies. First of all, conversation in translation is language, symbols and information carriers. Second, the purpose of translation is transmit, transfer, communicate, transplant or absorb the meaning, contents, information and culture in original contents.

B. Some examples of cultural fusion from the perspective of translation

When we read English articles, we often read "Lady Hermits" and "Lady hermits who are down but not out". We translate them into “女隐士们” and “潦而不倒的隐士们” and the translation has been accepted by most people. (TAN Huijuan, 1999: 65) But when you carefully study, you will find that the meaning of the two phrases are clear, but cannot make out their connotations if we don't study deeply. Why the lady hermits are "down but not out"? Actually, it implies a relatively deep social and cultural background of the United States. They hold a shopping bag, stroll in the street and sleep on the porch of others. They are homeless. Although they do not beg in the public, these women do not refuse others' alms either. They live in a small world of their own social isolation poorly and sadly. Despite having the low social status, they never yield to fate and remain unrequited love of life. And they have become a true portrayal of the American society of the wealth gap. It seems that it is not easy to be faithful to the original and the cultural connotation can not be avoided either.

British always contribute their thoughts to head. For example, "hard headed" means someone who have a cool head and clear mind; they also contribute their feelings to heart, such as "warm hearted", it means kind. And the word "mind" means that/which thinks, perceives, feels, wills, etc those are 
untouchable and unseen. As a saying goes, "Great minds think a like." This is the way it use. The antonym of " mind" is body. However " mind" often represents “心, 心力, 心胸” in Chinese. We often says, “absent minded (心不在焉)”, “out of sight, out of mind (眼不见, 心 不烦)", "Nothing in the world is difficult for one who sets his mind to do it. (世上无难事, 只怕有心人) ”. But in some respects, West people and Chinese people both consider that heart is the main tool to think. It is quite different from the English in which "head" represents thinking and "heart" symbolizes feeling.

\section{1) Cultural mediation in the translation of words and terms}

Russell wrote in What I have lived for: I have sought love, first because it brings ecstasy so great that I would often have sacrificed all the rest of life for a few hours of this joy. I have sought it, next, because it relives loneliness-that terrible loneliness in which one shivering consciousness looks over the rim of the world into the cold unfathomable lifeless abyss.

We can translate it into Chinese:

我曾追求爱, 首先是因为它能使人陶醉——使人深深 的陶醉, 以至于我愿牺牲全部雨声来换取片刻的这种欢 快。我曾追求爱, 其次是因为他能排遣孤独一一在这种孤 独中, 人的意识战战兢兢, 看破红尘, 俯视着那冰冷的、 死气沉沉的、深不可测的地狱。 (DU Zhengming, 2008: 33 )

There, we translate "looks over the rim of the world" into “看破滚滚红尘” because the word “rim” means the border, edge, or margin of an object. So, we may think about that what the "rim of the world" is, where the "rim" is and whether we can see the "rim of the world". The world "world" is not the physical world but the people of the world, the human society. Besides, the "rim" is also a abstract concept that people are restricted by thoughts. Then, we can understand the meaning of "rim of the world" and translate it into “滚滚红尘”.

\section{2) Cultural restructuring in translation of sentence}

Here is a sentence: Prue also told Clive that she has broken her engagement to a conscientious objector, and because she was ashamed for him she had joined the W.A.A.F.

We can pick the term "her engagement" and translate it into a sentence. If we translate according to the grammar directly, Chinese readers may feel unnatural. It does not conform to Chinese custom. In Chinese thoughts, we are used to be from beginning to the end and have both cause and effect. So we can translate it as follows.

普露还告诉克莱夫说自己曾于人订婚, 但由于对方借 故宗教良心拒服兵役, , 就解除了和他的婚约。正式由于 为他感到耻辱普露才参加了女子兵才。

3) Cultural interpretation in translation of sentence

When we translate paragraphs we need to not only focus on the cultural factors but also combine the context.

We can see from one poem called “天净沙 秋思” written by Ma Zhiyuan, Yuan dynasty. (Hu Wenzhong, 1999: 109)

枯藤老树昏鸦,

小桥流水人家。
古道西风瘦马,

夕阳西下,

断肠人在天涯。

Schlepp, a translator, translated it into English as follows:

Dry vine, old tree, crows at dust,

Low bridge, stream running, cottages,

Ancient road, west wind, lean nag,

The sun westing,

And one with breaking heart at the sky's edge.

The translation by Schlepp combine the rhythm of Chinese poetry and he try his best to keep the features of the poem. When translating the poem, the combine domestication and alienation. He avoid to obliterate the Chinese culture as far as possible.

\section{Conclusion}

Translation carries culture and promotes the exchange of different cultures.

To the aim of the cultural fusion, people should participate in the communication of Chinese and Western culture actively, establish the sense of confidence, and adopt the attitude of changing ourselves. They should try our best to learn cultures mutually.

Different nations have different cultures. Chinese and western people should accept the reality and keep the right attitude towards the difference and absorb the cultures mutually, by which the culture fusion can be realized.

\section{Acknowledgment}

My special thanks must go to Professor Liu Jinling who not only has taught me the computer knowledge but also has given me patient instruction during the course of writing the article.

\section{References}

[1] Bowmar, People and culture. Los Angeles: Bowmar Publishers, Inc, 1980.

[2] E.A. Nida, Language and Culture Contexts in Translating. Shanghai: Shanghai Foreign Language Education Press, 2001.

[3] E.A. Nida, Language, Culture and Translating. Shanghai: Shanghai Foreign Language Education Press, 1993.

[4] L.H ickey, The Pragmatics of Translation. Shanghai: Shanghai: Shanghai Foreign Language Education Press, 2001.

[5] P.N ewmark, A ownexperience of Translation. Shanghai: Shanghai Foreign Language Education Press, 2001.

[6] DU Zhengming, Culture and Translation Strategies. China Economic Publishing House, 2008.

[7] HE Ziran, Introduction toPragmatics. Hubei: Hubei Education Publishing House, 1988.

[8] HU Gengshen, Adaption and Option Theory in Translation. Hubei: Hubei Education Publishing House, 2004.

[9] HU Wenzhong, Introduction to Intercultural Communication. Beijing: Foreign Language Teaching and Research Press, 1999.

[10] HU Wenzhong, Beyond Culture Barrier. Beijing: Foreign Language Tteaching and Research Press, 2002.

[11] TAN Huijuan, Foreignization and Domestication in Translation from the Perspective of Cultural Differences and Penetration. Translation in China, 1999 (20) : 21. 